\title{
FERMENTED PUMPKIN-BASED BEVERAGE INHIBITS KEY ENZYMES OF CARBOHYDRATE DIGESTING AND EXTENUATES POSTPRANDIAL HYPERGLYCEMIA IN TYPE-2 DIABETIC RATS
}

\author{
W.Y. KoH ${ }^{\mathrm{a}}$, U. UthUmPORNa*, A. Rosma and K.H. YUen ${ }^{\mathrm{c}}$ \\ ${ }^{\text {a}}$ Food Technology Division, School of Industrial Technology, Universiti Sains Malaysia, Minden 11800, Penang. \\ Malaysia \\ ${ }^{\mathrm{b}}$ Bioprocess Technology Division, School of Industrial Technology, Universiti Sains Malaysia, Minden 11800, \\ Penang. Malaysia \\ ${ }^{\mathrm{c}}$ Discipline of Pharmacology, School of Pharmaceutical Sciences, Universiti Sains Malaysia, 11800 Minden, \\ Penang. Malaysia
}

(Received: 7 March 2018; accepted: 4 May 2018)

\begin{abstract}
A novel functional pumpkin-based beverage fermented by Lactobacillus mali K8 (FPJ) was produced. FPJ possessed higher ferric reducing antioxidant power (FRAP, $270.76 \mu \mathrm{M} \mathrm{TE} / 100 \mathrm{ml}$ ) and radical scavenging activity (RSAIC50, $\left.7.56 \mathrm{mg} \mathrm{ml}^{-1}\right)$ compared with non-inoculated control (PJ) $\left(102.99 \mu \mathrm{M} \mathrm{TE} / 100 \mathrm{ml}\right.$ and IC50 $\left.52.78 \mathrm{mg} \mathrm{ml}^{-1}\right)$. Up to an IC50 of 23.71 and $5.27 \mathrm{mg} \mathrm{ml}^{-1}$ of $\alpha$-amylase and $\alpha$-glucosidase inhibitions were demonstrated by FPJ, close to that of acarbose (IC50 4.86 and $0.048 \mathrm{mg} \mathrm{ml}^{-1}$, respectively). Oral administration of FPJ significantly lowered post-meal blood glucose levels in low-dose streptozotocin (STZ) and high-fat diet-treated rat - a reduction of incremental areas under the curve 2334 versus $2689 \mathrm{mmol} \mathrm{min} 1^{-1}$. Thus, it may open new dietary measure in managing postprandial hyperglycaemia.

Keywords: $\alpha$-glucosidase, postprandial hyperglycaemia, antioxidant, anti-diabetic
\end{abstract}

In type-2 diabetes (T2D), postprandial hyperglycaemia could be lowered by inhibiting carbohydrate digesting enzymes ( $\alpha$-amylase and $\alpha$-glucosidase) (Thilagam et al., 2013). Starch is hydrolyzed by pancreatic $\alpha$-amylase into oligosaccharides, which is further hydrolyzed by $\alpha$-glucosidase into glucose in the jejunum (HAMID et al., 2015). Therefore, glucose absorption could be delayed by impeding these enzymes and thus suppressing the postprandial blood glucose levels. Drugs such as miglitol, acarbose, and voglibose used in reducing postprandial hyperglycaemia are often associated with side effects (SousA et al., 2016). Therefore, this work focused on characterization of FPJ developed in the previous study from pumpkin fruit (KoH et al., 2018a) and PJ regarding their nutritional benefits, antioxidant capacities, and anti-hyperglycaemic effect in vitro and in vivo as a dietary measure to improve postprandial hyperglycaemia with fewer side effects.

\section{Materials and methods}

\subsection{Lactobacillus mali $K 8$ cultures}

K8 strain was isolated from water kefir grains obtained from Cultures for Health ${ }^{\mathrm{SM}}$ (Morrisville, NC, USA) and was identified as Lactobacillus mali by $16 \mathrm{~S}$ rRNA sequencing

\footnotetext{
* To whom correspondence should be addressed. Phone: +604-6532220; e-mail: sapina@usm.my
} 
with accession number NR_112691.1. (KoH et al., 2018b). The L. mali K8 strain was kept in De Man, Rogosa and Sharpe (MRS) broth (Merck, Darmstadt, Germany) with 20\% v/v glycerol at $-80^{\circ} \mathrm{C}$. Before used as an inoculum to ferment FPJ, the strain was sub-cultured at least once in MRS broth $\left(37^{\circ} \mathrm{C}, 24 \mathrm{~h}\right)$.

\subsection{Fermentation of pumpkin-based beverage}

FPJ and PJ beverage samples were prepared aseptically according to $\mathrm{KoH}$ and co-workers (2018a) (Fig. 1). Fresh FPJ and PJ samples were centrifuged (13 $\left.362 \mathrm{~g}, 15 \mathrm{~min}, 4^{\circ} \mathrm{C}\right)$, then filtered through $0.22 \mu \mathrm{m}$ PTFE membrane and kept in screw-capped amber bottles in a freezer $\left(-20^{\circ} \mathrm{C}\right)$ for enzymes inhibition assays, phenolic acids and antioxidants analyses. FPJ and PJ were stored at $4{ }^{\circ} \mathrm{C}$ for other analyses.

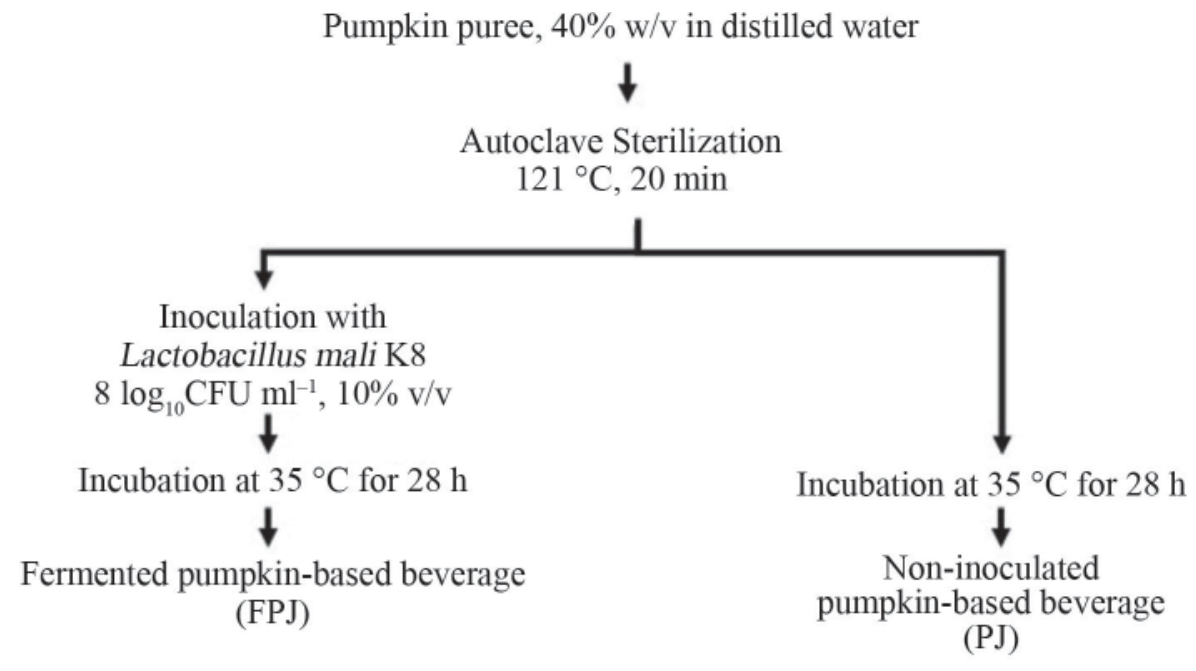

Fig. 1. Overall processes performed for PJ and FPJ production (KoH et al., 2018a).

\subsection{Proximate, $p H$, total solids and sugar contents}

Proximate composition of PJ and FPJ such as moisture (967.08), ash (942.05), protein (988.05), fat (2003.06), and dietary fiber (991.43) contents were quantified (AOAC, 2005). Total and available carbohydrate content was calculated by difference. The samples were also evaluated for calorie (energy factors), $\mathrm{pH}$ (electrometric process), sugar ${ }^{\circ}$ Brix (digital refractometer direct reading), and total solids \% (100 minus moisture content).

\subsection{Instrumental analyses (mineral, phenolic acid, and ethanol contents)}

The ethanol, mineral, and phenolic acid contents of PJ and FPJ were analysed using gas chromatograph-mass spectrometer (Shimadzu QP2010 plus, Tokyo, Japan), inductively coupled plasma mass spectrometry (Perkin Elmer Nexion 300, Wellesley, MA, USA), and high-performance liquid chromatography with photodiode array detector (Waters 2690 Alliance, Milford MA, USA), respectively. 


\subsection{Antioxidant contents and capacities}

RSA, FRAP, phenolic, flavonoid, and carotenoid contents of PJ and FPJ were determined by colourimetric method (SYAHARIZA et al., 2017). The IC50 (half-maximum inhibitory concentration) value $\left(\mathrm{mg} \mathrm{ml}^{-1}\right)$ of RSA was calculated.

\section{6. $\alpha$-Amylase and $\alpha$-glucosidase enzymes inhibition}

The $\alpha$-amylase and $\alpha$-glucosidase enzymes inhibition of PJ, FPJ, and acarbose were determined separately using $\alpha$-amylase enzyme (EC 3.2.1.1) from porcine pancreas (SigmaAldrich, Inc., St Louis, MO, USA) (SAHA \& Verma, 2012), and $\alpha$-glucosidase enzyme extracted from rat intestinal acetone powder (Sigma-Aldrich, I1630) (KoH et al., 2018), respectively. The IC50 value $\left(\mathrm{mg} \mathrm{m}^{-1}\right)$ of the enzymes' activity was calculated.

\subsection{Effect on postprandial glycaemic responses in vivo}

FPJ, which inhibited $\alpha$-amylase and $\alpha$-glucosidase better than PJ, was selected for in vivo study. Animal Research and Service Centre, Penang, Malaysia provided 48 male SpragueDawley (SD) rats (300 g, three-month-old), which were acclimated to laboratory environment for a week and had free access to food and water ad libitum. Normal diet (Altromin, Lage, Germany) was fed to 24 randomly selected rats and high-fat diet (Altromin) was fed to the other rats for four weeks. The 12-h fasted rats were injected intraperitoneally with $40 \mathrm{mg} \mathrm{kg}^{-1}$ body weight (BW) STZ. After 48 h, 12-h fasting blood glucose (FBG) was measured. Rats with FBG $>11.1 \mathrm{mmol} \mathrm{l}^{-1}\left(200 \mathrm{mg} \mathrm{dl}^{-1}\right)$ were regarded as T2D (JIAO et al., 2017). Handling of these animals complied with policies and regulations of Universiti Sains Malaysia (USM) Institutional Animal Care and Use Committee under animal ethics approval number: USM/ Animal Ethics Approval/2017/(105)(841).

Normal rats and STZ-induced diabetic rats were fasted $12-\mathrm{h}$ and randomly divided into three groups of eight rats (Fig. 2). To each group starch solution $\left(2 \mathrm{~g} \mathrm{~kg}^{-1} \mathrm{BW}\right)$ together with acarbose $\left(10 \mathrm{mg} \mathrm{kg}^{-1} \mathrm{BW}\right)$, or FPJ (9 $\log 10 \mathrm{CFU} \mathrm{ml^{-1 }}$ per rat), or distilled water (control), respectively, were orally administered. Tail vein blood samples were tested with AccuCheck glucometer (Roche Diagnostics, Lewes, UK) at 0, 30, 60, and $120 \mathrm{~min}$. Incremental area under the curve (AUC) was calculated using trapezoidal rule $\left(\mathrm{mmol} \mathrm{min} \mathrm{l}^{-1}\right)$.

\subsection{Microbiological risk and sensory evaluation}

Weekly enumeration of Bacillus cereus, Staphylococcus aureus, Escherichia coli, Salmonella, and total coliform count of refrigerated $\left(4{ }^{\circ} \mathrm{C}\right) \mathrm{FPJ}$ samples were conducted for 56 days (APHA, 2015), followed by weekly sensory hedonic evaluation of refrigerated FPJ samples as described by KоH and co-workers (2018a).

\subsection{Statistical analysis}

All results are presented as mean values \pm standard error of six measurements (duplicated for three independent productions) and analysed by SPSS software version 21.0 (IBM, Armonk, NY, USA). Differences between means obtained in each PJ and FPJ parameters were evaluated by paired-sample $t$-tests. Differences among means obtained in determination of glycaemic response and incremental AUC were evaluated by one-way ANOVA followed by Tukey's test. $\mathrm{P}<0.05$ is statistically significant. 


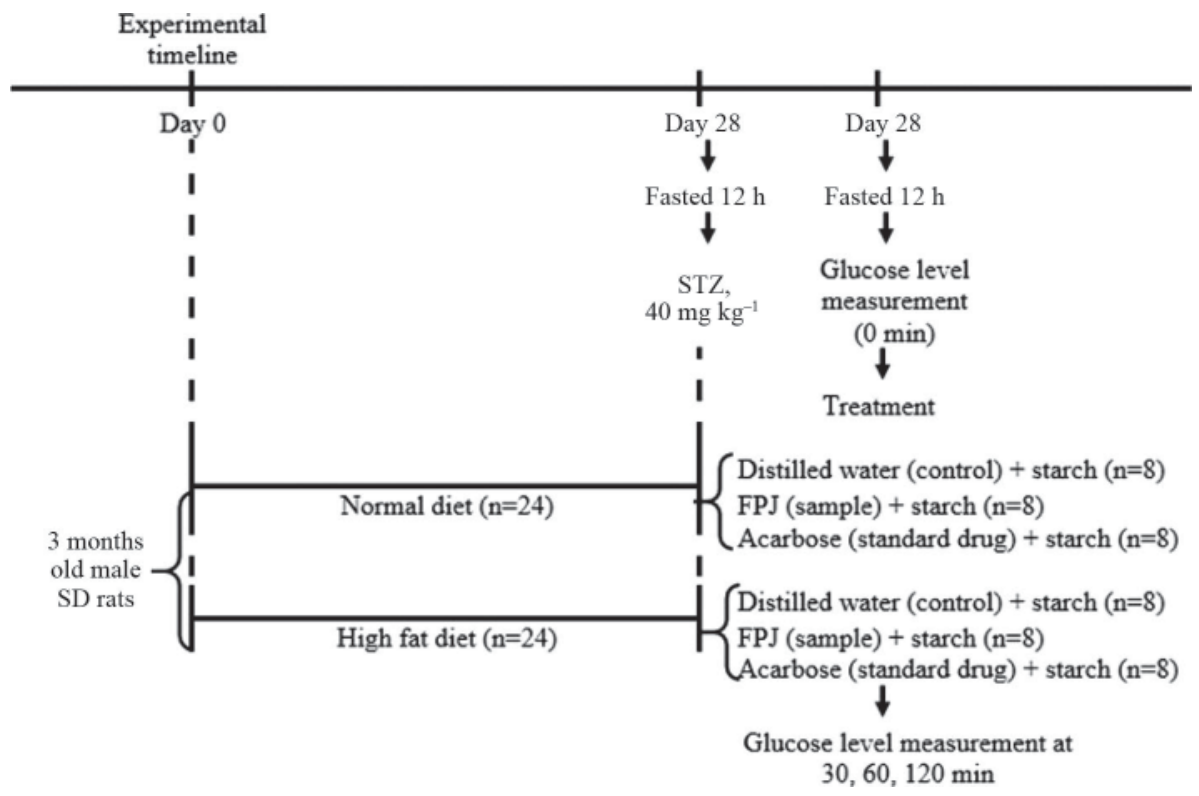

Fig. 2. Experimental design for in vivo study of FPJ's effect on postprandial blood glucose

\section{Results and discussion}

\subsection{Chemical composition}

As shown in Table 1, FPJ contained lower $(\mathrm{P}<0.05)$ amounts of moisture, carbohydrate, fibre, and fat than PJ due to lactobacilli growth, enzymatic hydrolyzation, and lipolysis during fermentation (OBADINA et al., 2013). Higher ethanol content observed in FPJ compared to PJ was due to lactic acid heterofermentation (SALMERON et al., 2009). This also contributed to higher protein, ash, and mineral contents in FPJ compared to PJ due to the amino acids and minerals released by lactobacilli (OBADINA et al., 2013). IfESAN and co-workers (2014) corroborated these findings. 
KOH et al.: FERMENTED PUMPKIN BEVERAGE

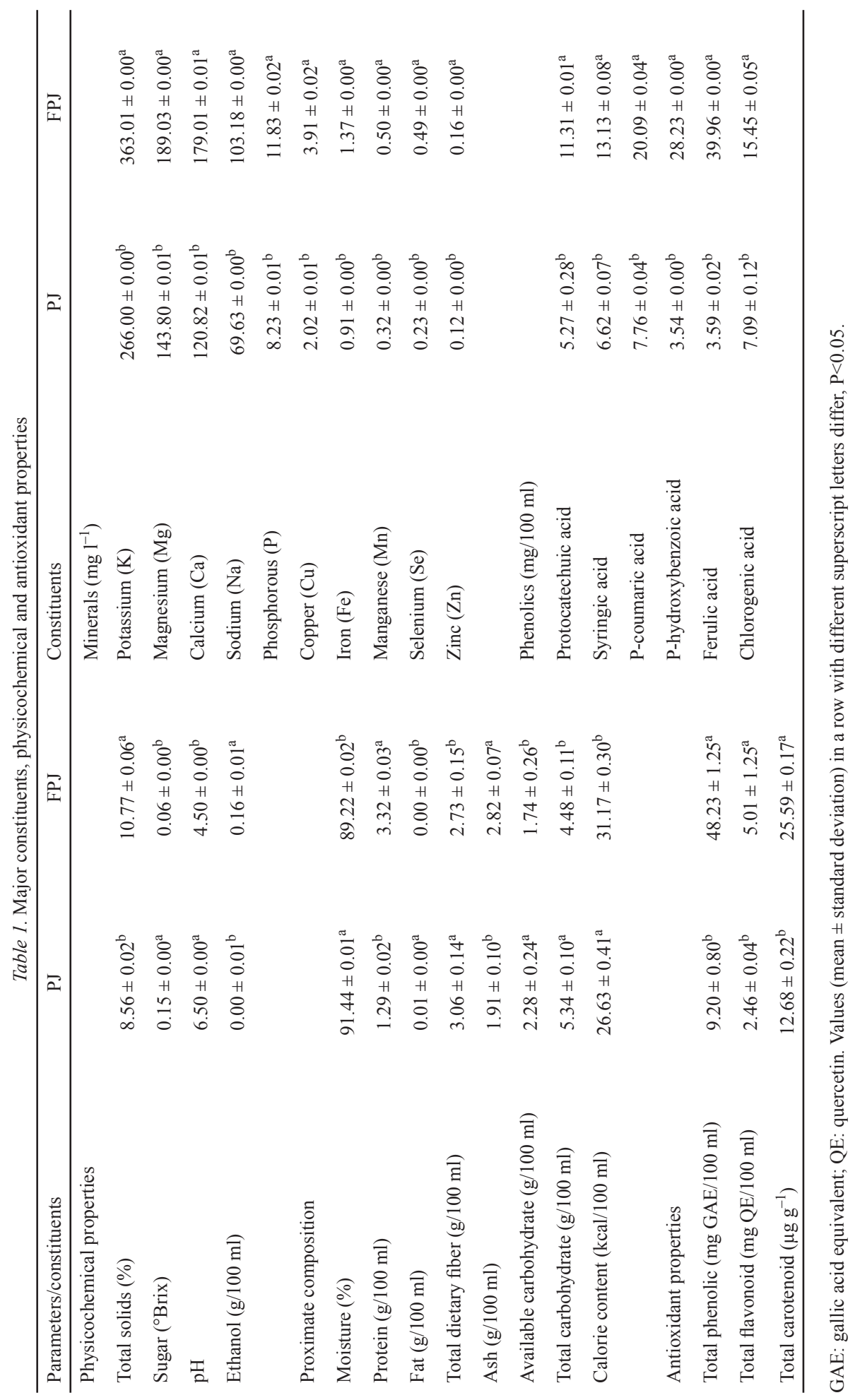




\subsection{Antioxidant capacities, antioxidant contents, and phenolic acids}

Data presented in Tables 1 and 2 show significant elevation in dietary antioxidant contents, phenolic acids, FRAP, and 2,2-diphenyl-1-picrylhydrazyl free radical scavenging activity (DPPH) in FPJ compared to PJ. This elevation could be due to depolymerization of conjugated phenolic compounds by (poly) phenoloxidases of lactobacilli (KwAw et al., 2018). Similar results were observed in lactic-acid-fermented mulberry juice (KwAw et al., 2018) and sweet lemon juice (HASHEMI et al., 2017).

Table 2. In vitro antioxidant and anti-diabetic activities

\begin{tabular}{lcc}
\hline & PJ & FPJ \\
\hline DPPH IC50 $\left(\mathrm{mg} \mathrm{ml}^{-1}\right)$ & $52.78 \pm 0.00^{\mathrm{a}}$ & $7.56 \pm 0.03^{\mathrm{b}}$ \\
FRAP $(\mu \mathrm{M} \mathrm{TE} / 100 \mathrm{ml})$ & $102.99 \pm 0.02^{\mathrm{b}}$ & $270.76 \pm 0.00^{\mathrm{a}}$ \\
$\alpha$-Glucosidase inhibitory activity IC50 $\left(\mathrm{mg} \mathrm{m}^{-1}\right)$ & $124.95 \pm 0.00^{\mathrm{a}}$ & $5.27 \pm 0.00^{\mathrm{b}}\left(0.048 \pm 0.00^{\mathrm{c}}\right)$ \\
$\alpha$-Amylase inhibitory activity IC50 $\left(\mathrm{mg} \mathrm{ml}^{-1}\right)$ & $65.83 \pm 0.00^{\mathrm{a}}$ & $23.71 \pm 0.00^{\mathrm{b}}\left(4.86 \pm 0.00^{\mathrm{c}}\right)$ \\
\hline
\end{tabular}

Values are given as mean \pm standard deviation. Lower IC50 value means higher enzyme inhibition/antioxidant activity. Figures in parenthesis are IC50 values obtained for acarbose. TE: Trolox equivalent; different lowercase letters in the same rows differ significantly $(\mathrm{P}<0.05)$.

\section{3. $\alpha$-Amylase and $\alpha$-glucosidase inhibition}

Table 2 shows that FPJ had lower $\alpha$-amylase and $\alpha$-glucosidase IC50 values compared to PJ, most likely due to increased post-fermentation phenolics and flavonoids (Table 1) (FuJITA et al., 2017). IC50 for $\alpha$-amylase of FPJ $\left(23.71 \mathrm{mg} \mathrm{ml}^{-1}\right)$ was higher than lactic-acid-fermented noni $\left(2.35 \mathrm{mg} \mathrm{ml}^{-1}\right)$ (LeE et al., 2016). However, IC50 for $\alpha$-glucosidase of FPJ $\left(5.27 \mathrm{mg} \mathrm{m}^{-1}\right)$ was lower than of the fermented noni (11.29 $\left.\mathrm{mg} \mathrm{ml}^{-1}\right)($ LeE et al., 2016). JIN and co-workers (2013) reported that pumpkin-rich diets prevented excessive blood glucose increment after carbohydrate intake, which might be due to $\alpha$-glucosidase inhibition activity of pumpkin polysaccharides (Song et al., 2012). $\alpha$-Glucosidase inhibition in FPJ also correlated to increased concentration of aglycones by $\beta$-glucosidase activity of lactobacilli during fermentation (FuJITA et al., 2017).

Acarbose had lower $\alpha$-amylase and $\alpha$-glucosidase IC50 values compared to FPJ (Table 2 ), but complete inhibition of $\alpha$-amylase can cause excessive undigested starch being utilized by gut microflora, resulting in carbohydrate intolerance and gastrointestinal side effects (HAmid et al., 2015). Therefore, FPJ, which possessed mild $\alpha$-amylase inhibition and strong $\alpha$-glucosidase inhibition, could serve as a safe pharmaco-nutritional strategy to prevent T2D. Thus, it was chosen for subsequent in vivo study.

\subsection{Postprandial blood glucose level effects}

Postprandial blood glucose levels of the FPJ-administered T2D rats were lower than T2D control rats (Fig. 3A). In T2D control rats, blood glucose levels were elevated to 24.03 $\mathrm{mmol} \mathrm{l}^{-1}$ at $60 \mathrm{~min}$ post-starch administration, followed by significant decrease due to glucose homeostasis $\left(22.40 \pm 0.44,24.03 \pm 1.00\right.$ and $23.03 \pm 0.90 \mathrm{mmol} \mathrm{l}^{-1}$ at 30,60 , and $120 \mathrm{~min}$, respectively; $\mathrm{P}<0.05$ ). However, postprandial blood glucose increment was suppressed after 
FPJ was administered with starch $\left(19.33 \pm 0.65,20.91 \pm 0.94\right.$ and $18.87 \pm 0.65 \mathrm{mmol} \mathrm{l}^{-1}$ at 30 , 60 , and 120 min, respectively; $\mathrm{P}<0.05$ ). Postprandial blood glucose increment was also suppressed when the normal rats were administered FPJ with starch (Fig. 3B).

In T2D rats, the incremental AUC for glucose response of FPJ-administered group $\left(2334 \pm 79 \mathrm{mmol} \mathrm{min} \cdot \mathrm{l}^{-1}\right)$ was significantly lower than of control $\left(2692 \pm 32 \mathrm{mmol} \mathrm{min} \cdot \mathrm{l}^{-1}\right)$ (Fig. 3C). Similar trend was also observed in normal rats. Similar findings were reported for apple and blackcurrant polyphenol-rich drinks (CASTRO-Acosta et al., 2017). Dietary supplementation with Lactobacillus mali strain also effectively maintained blood glucose level in high-fat diet-induced obese mice (LiN et al., 2016). Hence, FPJ is proposed as a dietary measure to improve postprandial hyperglycaemia.
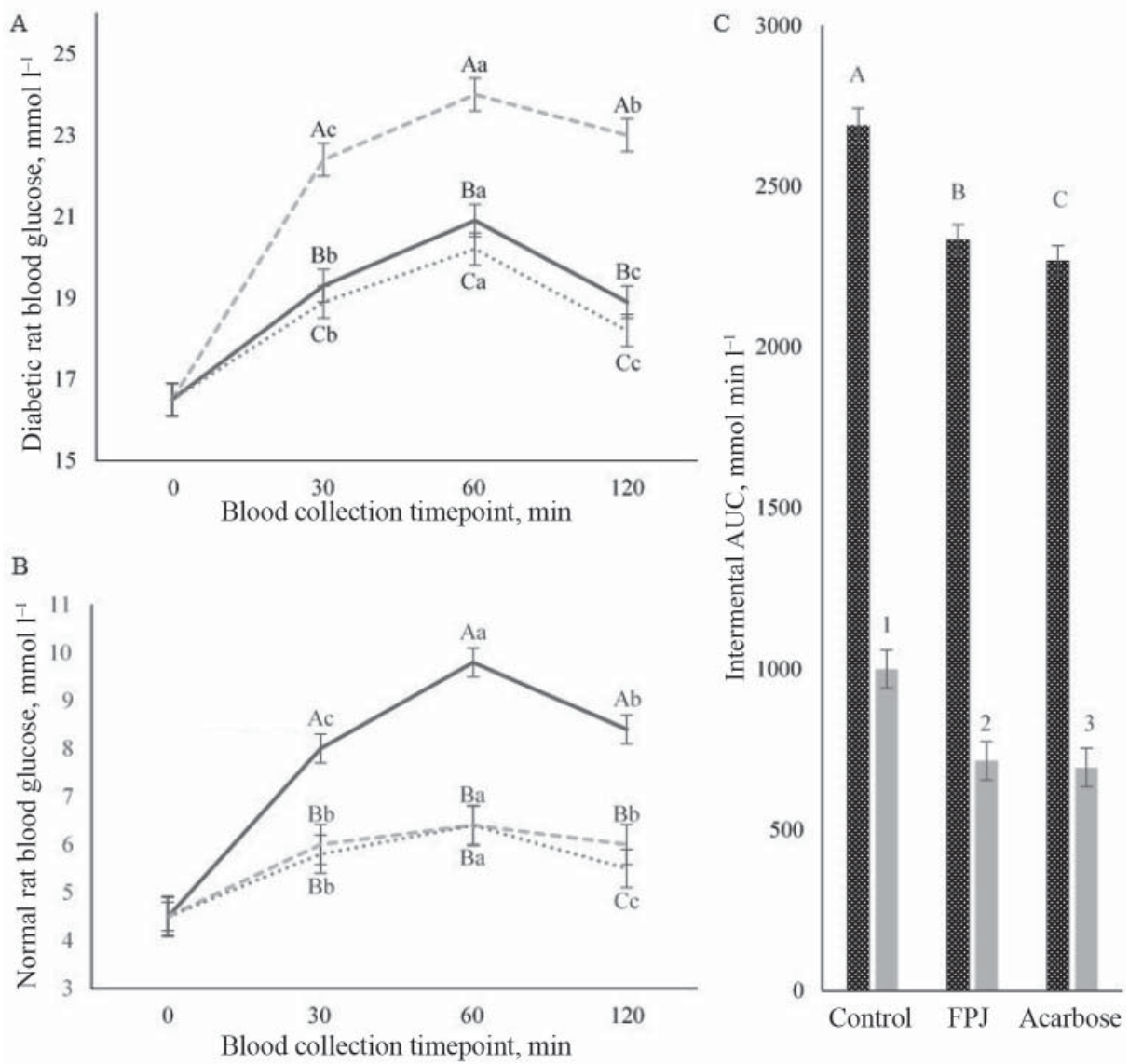

B

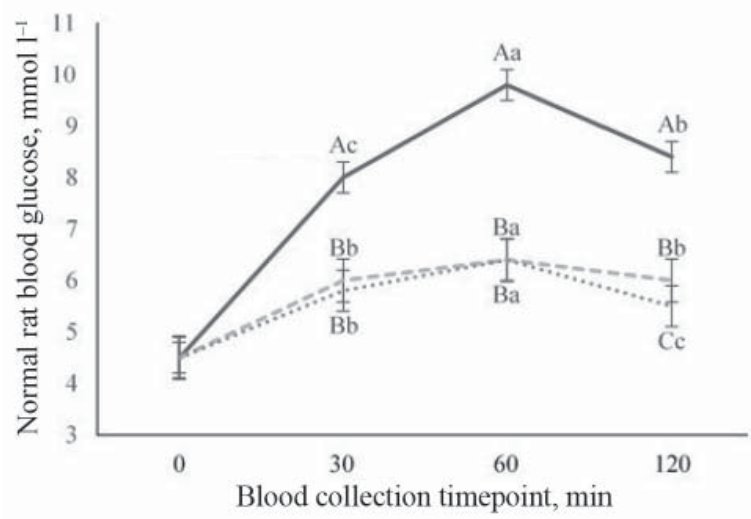

Fig. 3. Glycaemic response curve in post-FPJ/acarbose administered high-fat diet-fed and low-dose STZinduced T2D rats (A); normal rats (B); AUC0-120 min, incremental area under the curve in T2D and normal rats after starch administration (C). Three treatment groups: control (distilled water); acarbose $\left(10 \mathrm{mg} \mathrm{kg}^{-1}\right)$; FPJ (9 $\log 10 \mathrm{CFU} \mathrm{ml} l^{-1}$ per rat), was administered with starch $\left(2 \mathrm{~g} \mathrm{~kg}^{-1}\right)$ using oral gavage. Each value represents mean \pm standard deviation of eight rats per group $(n=48)$. Values with different lowercase alphabets $(a-c)$ are significantly different between time $(\mathrm{min})$; uppercase alphabets $(\mathrm{A}-\mathrm{C})$ and number $(1-3)$ are significantly different between treatment groups.
(A) _ _ _: Control; __ : FPJ; ..... . Acarbose
(B) __ Control; _ _ _: FPJ; ..... : Acarbose
(C) 嗞: Diabetic rat; : Normal rat 


\subsection{Microbiological risk and sensory evaluation}

No coliforms, B. cereus, S. aureus, E. coli O157:H7, and Salmonella spp. were detected in any refrigerated FPJ sample throughout 56 days of weekly microbiological testing, therefore the FPJ samples were safe for sensory evaluation.

Figure 4 shows that FPJ scored consistently for all sensory attributes ranging from 6.99 (good to excellent) to 4.00 (acceptable) throughout 49 days of refrigerated storage, which was within the acceptable limit (corresponding to a score $\geq 3.00$ ). The scores for all sensory attributes at day 56 decreased to $\leq 2.00$ (defined as unacceptable) (Speranza et al., 2012), indicating that the proposed FPJ had a shelf life of 49 days. This decrease is most likely due to depleted fermentable carbohydrates at the end of the storage period resulting in carbonsource starvation stress in lactobacilli cells, which caused adaptive morphological changes and lactic acid bacteria spoilage, such as off-odors and discoloration (BUCKA-KOLENDO \& SOKOLOWSKA, 2017).

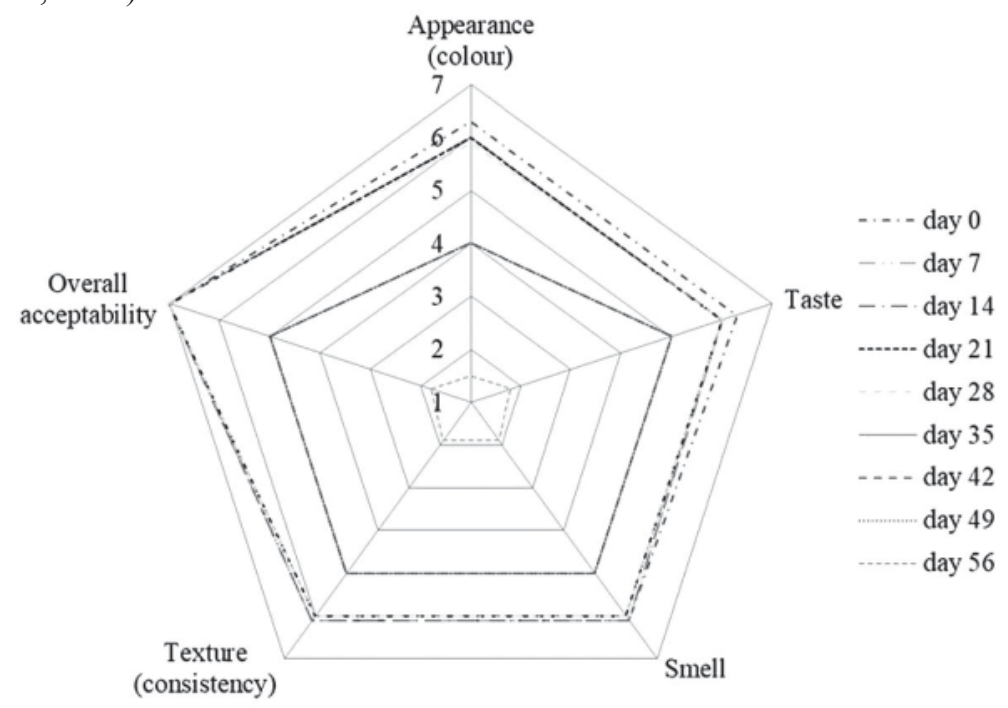

Fig. 4. Hedonic sensory evaluation of FPJ stored at $4{ }^{\circ} \mathrm{C}$ for 56 days (KoH et al., 2018a).

\section{Conclusions}

FPJ possesses beneficial dietary nutrients and antioxidants, mild $\alpha$-amylase and strong $\alpha$-glucosidase inhibitory activities, as well as suppressed postprandial blood glucose elevation. Thus, it may alleviate postprandial hyperglycaemia in T2D patients.

This work was supported by the USM under Research University Grant (1001/PTEKIND/811339), Vice-Chancellor Award Scholarship, and ASEAN University Network Korea Exchange Fellowship.

\section{References}

AOAC (2005): Official Methods of Analysis. Association of Official Analytical Chemists, 18th ed. Gaithersburg, M.D.

APHA (2015): Compendium of methods for the microbiological examination of foods. 5th ed. American Public Health Association, Washington, D.C. 
Bucka-Kolendo, J. \& SokolowsKa, В. (2017): Lactic acid bacteria stress response to preservation processes in the beverage and juice industry. Acta Biochim. Pol., 64, 459-464.

Castro-Acosta, M.L., Stone, S.G., Mok, J.E., Mhajan, R.K., Fu, C.I., Lenihan-Geels, G.N., Corpe, C.P. \& Hall, W.L. (2017): Apple and blackcurrant polyphenol-rich drinks decrease postprandial glucose, insulin and incretin response to a high-carbohydrate meal in healthy men and women. J. Nutr. Biochem., 49, 53-62.

Fujta, A., SARKar, D., Genovese, M.I. \& ShetTy, K. (2017): Improving anti-hyperglycemic and anti-hypertensive properties of camu-camu (Myriciaria dubia Mc. Vaugh) using lactic acid bacterial fermentation. Process Biochem., 59, 133-140.

HAMid, H.A., Yusoff, M.M., Liv, M. \& KaRim, M.R. (2015): $\alpha$-Glucosidase and $\alpha$-amylase inhibitory constituents of Tinospora crispa: Isolation and chemical profile confirmation by ultra-high performance liquid chromatography-quadrupole time-of-flight/mass spectrometry. J. Funct. Foods, 16, 74-80.

Hashemi, S.M.B., Mousavi Khaneghah, A., Barba, F.J., Nemati, Z., Sohrabi Shokofti, S. \& Alizadeh, F. (2017): Fermented sweet lemon juice (Citrus limetta) using Lactobacillus plantarum LS5: Chemical composition, antioxidant and antibacterial activities. J. Funct. Foods, 38, 409-414.

IfEsAn, B.O.T., EgBEwole, O.O. \& IfesAn, B.T. (2014): Effect of fermentation on nutritional composition of selected commonly consumed green leafy vegetables in Nigeria. Int. J. Appl. Sci. Biotech. (IJASBT), 2, 291-297.

JiAo, Y., Wang, X., JiAng, X., Kong, F., WANG, S. \& YAn, C. (2017): Antidiabetic effects of Morus alba fruit polysaccharides on high-fat diet- and streptozotocin-induced type 2 diabetes in rats. J. Ethnopharmacol., 199, $119-127$.

Jin, H., Zhang, Y.-J.J., Jiang, J.-X.X., Zhu, L.-Y.Y., Chen, P., Li, J. \& Yao, H.-Y.Y. (2013): Studies on the extraction of pumpkin components and their biological effects on blood glucose of diabetic mice. J. Food Drug Anal., $21,184-189$.

KoH, W.Y., Uthumporn, U., Rosma, A., Irfan, R. \& PARK, Y.H. (2018a): Optimization of a fermented pumpkin-based beverage to improve Lactobacillus mali survival and $\alpha$-glucosidase inhibitory activity: A response surface methodology approach. Food Science and Human Wellness, 7(1), 57-70.

Koh, W.Y., Uthumporn, U., Rosma, A., Irfan, R. \& Park, Y.H. (2018b): Evaluation of probiotic potential and antihyperglycemic properties of a novel Lactobacillus strain isolated from water kefir grains. Food Sci. Biotechnol., 1-8. available at: https://doi.org/10.1007/s10068-018-0360-y (last accessed Oct 5, 2018).

Kwaw, E., Ma, Y., Tchabo, W., Tibiru, M., Wu, M., Sackle, A., Xiao, L. \& Elrasheid, H. (2018): Effect of Lactobacillus strains on phenolic profile, color attributes and antioxidant activities of lactic-acid-fermented mulberry juice. Food Chem., 250, 148-154.

LeE, H.H., Y IN, L.J., TAI, H.M. \& JiAng, S.T. (2016): Facilitating the release of bionutrients from Morinda citrifolia (noni) by cellulase hydrolysis and lactic acid bacteria fermentation and their effects on $\alpha$-amylase and $\alpha$-glucosidase activities. J. Mar. Sci. Tech .- Japan, 24, 648-655.

Lin, Y.C., Chen, Y.T., Hsien, H.H. \& CHen, M.J. (2016): Effect of Lactobacillus mali APS1 and L. kefiranofaciens M1 on obesity and glucose homeostasis in diet-induced obese mice. J. Funct. Foods, 23, 580-589.

Obadina, A.O., Akinola, O.J., Shittu, T.A. \& Bakare, H.A. (2013): Effect of natural fermentation on the chemical and nutritional composition of fermented soymilk Nono. Nigerian Food J., 31, 91-97.

SAHA, S. \& Verma, R. (2012): Inhibitory potential of traditional herbs on $\alpha$-amylase activity. Pharm. Biol., 50, $326-331$

Salmeron, I., Fucinos, P., Charalampopoulos, D. \& Pandiella, S.S. (2009): Volatile compounds produced by the probiotic strain Lactobacillus plantarum NCIMB 8826 in cereal-based substrates. Food Chem., 117, 265-271.

Song, Y., Zhang, Y., Zhou, T., Zhang, H., Hu, X. \& Li, Q. (2012): A preliminary study of monosaccharide composition and $\alpha$-glucosidase inhibitory effect of polysaccharides from pumpkin (Cucurbita moschata) fruit. Int. J. Food Sci. Tech., 47, 357-361.

Sousa, J., Turnes, C., Deolindo, P., Antônio, L., Inés, M., Fujta, A., Boscacci, M., Deliberali, N., Daguer, H., CAmargo, A. \& Granato, D. (2016): Effects of time and extraction temperature on phenolic composition and functional properties of red rooibos (Aspalathus linearis). Food Res. Int., 89, 476-487.

Speranza, B., Bevilacqua, A., Sinigaglia, M. \& Corbo, M.R. (2012): Shelf life definition for Italian anchovies inoculated with Lactobacillus plantarum and Bifidobacterium animalis subsp. lactis. Innov. Food Sci. Emerg., $16,171-180$

Syahariza, Z.A., Torkamani, A.E., Norziah, H.M., Mahmood, W.A.K. \& Juliano, P. (2017): Optimisation of pressurised liquid extraction for antioxidative polyphenolic compound from Momordica charantia using response surface methodology. Int. J. Food Sci. Tech., 52, 480-493.

Thilagam, E., Parimaladevi, B., Kumarappan, C. \& Chandra Mandal, S. (2013): $\alpha$-Glucosidase and $\alpha$-amylase inhibitory activity of Senna surattensis. Journal of Acupuncture and Meridian Studies (JAMS), 6, 24-30 